\title{
Physiological responses of postlarval and juvenile blue crabs Callinectes sapidus to hypoxia and anoxia
}

\author{
Richard A. Tankersley*, Maria G. Wieber \\ Department of Biological Sciences, 1000 Hilltop Circle, University of Maryland Baltimore County, Baltimore, Maryland 21250, USA
}

\begin{abstract}
The influence of hypoxia and anoxia on the oxygen consumption, survivorship and rate of metamorphosis of field-caught postlarvae (megalopae) and first-instar juveniles of the blue crab Callinectes sapidus was observed under laboratory conditions. Rates of oxygen uptake by megalopae were independent of $P_{\mathrm{O}_{2}}$ at oxygen tensions above $8.88 \mathrm{kPa}$. However, $P_{c}$ for juvenile crabs was significantly higher than for megalopae ( 89.6 vs $43.2 \%$ saturation). Tolerance of blue crab megalopae of hypoxic conditions below $20 \%$ saturation $(\sim 4.12 \mathrm{kPa})$ was greater than for newly metamorphosed juveniles. Juvenile crabs also succumbed to the effects of anoxia more rapidly than megalopae, but neither group survived exposure of $>5 \mathrm{~h}$. Megalopae and crabs that became immobile in anoxic water quickly recovered when returned to normoxic conditions. Metamorphosis of megalopae to the first-juvenile stage was delayed when they were exposed to $P_{\mathrm{O}_{2}}$ values of 8.21 and $12.32 \mathrm{kPa}$ (40 and $60 \%$ saturation). Similarly, time to metamorphosis increased significantly when megalopae were temporarily exposed to hypoxic conditions $\left(P_{\mathrm{O}_{2}}=4.12 \mathrm{kPa}\right)$ for $4 \mathrm{~h}$ each day. However, there was no significant difference between the time to metamorphosis for megalopae exposed to hypoxic conditions for $2 \mathrm{~h}$ each day and those maintained in oxygen-saturated water. These results suggest that the presence of hypoxic and anoxic water in deep water layers and shallow near-shore habitats of estuaries during the summer months may influence the onshore migration, settlement and survival of blue crab megalopae and newly metamorphosed juvenile crabs
\end{abstract}

KEY WORDS: Callinectes sapidus - Blue crab - Respiration - Hypoxia - Anoxia - Megalopae - Juveniles · Metamorphosis · Survivorship

\section{INTRODUCTION}

Many benthic marine invertebrates live in areas that regularly experience reductions in dissolved oxygen concentrations. In estuarine and shallow coastal habitats, the occurrence of hypoxic and anoxic water masses is a seasonal phenomenon resulting from the combined effects of eutrophication, increased organic loading and water column stratification (e.g. Falkowski et al. 1980, Officer et al. 1984, Kuo \& Neilson 1987, Breitburg 1990, Sanford et al. 1990). Bottom water oxygen depletion in the summer may last for several weeks,

\footnotetext{
- Present address: Department of Biological Sciences, Florida Institute of Technology, 150 West University Blvd, Melbourne, Florida 32901, USA. E-mail: rtankers@fit.edu
}

and concentrations often reach levels that are phy siologically stressful or lethal to animals (see Diaz \& Rosenberg 1995 for review), resulting in massive faunal mortality (e.g. Steimle \& Sinderman 1978, Rosenberg \& Loo 1988, Rosenberg et al. 1990) and emigration from affected habitats (Baden et al. 1990, Pihl et al. 1991). Reduced oxygen concentrations are also common in shallow near-shore habitats, such as seagrass beds and salt marshes. These areas frequently experience short-term diel fluxes in dissolved oxygen with hypoxic periods occurring during late night/early morning hours as a result of plant and animal respiration in the absence of photosynthesis (Johnson \& Welsh 1985, Kenney et al. 1988, Fitt \& Coon 1992, Asmus et al. 1994, Cochran \& Burnett 1996). Since shallow nearshore habitats often serve as important settlement and 
refuge sites for commercially and ecologically important estuarine-dependent species, such as the blue crab Callinectes sapidus (Rathbun) (e.g. Orth \& van Montfrans 1987, 1990, Sogard \& Able 1991, Ruiz et al. 1993, and references therein), periodic or intermittent hypoxia may reduce their suitability as nursery areas by affecting the composition and abundance of benthic macrofauna (e.g. Santos \& Simon 1980, Harper et al. 1981, Officer et al. 1984, Gaston 1985, Llansó 1992, Diaz \& Rosenberg 1995), altering trophic interactions (Pihl et al. 1992, Breitburg et al. 1997), or increasing the susceptibility of resident species to predation (Poulin et al. 1987, Rahel \& Kolar 1990, Pihl et al. 1992, Breitburg et al. 1994, 1997)

Numerous studies have examined the behavioral and physiological responses of benthic invertebrates, including Callinectes sapidus, to hypoxia and anoxia (see reviews by Taylor 1982, Cameron 1989, Grieshaber et al. 1994, Diaz \& Rosenberg 1995). Field observations indicate that adult and juvenile blue crabs escape mortality by avoiding hypoxic bottom water and migrating to shallower areas (Pihl et al. 1991). However, in laboratory assays juvenile $C$. sapidus failed to exhibit any significant avoidance behaviors in response to hypoxic or anoxic water (Das \& Stickle 1994). Physiological tolerance of blue crabs to low oxygen conditions is also limited. Adult crabs are more tolerant of moderate hypoxia $\left(P_{\mathrm{O}_{2}} \geq 6.7 \mathrm{kPa}\right)$ than juveniles, but neither group is able to survive even short periods of severe hypoxia (Carpenter \& Cargo 1957. Stickle et al. 1989, deFur et al. 1990, Das \& Stickle 1993)

Although the effect of hypoxia on the physiology and behavior of adult crustaceans is well documented (for reviews see Wovlekamp \& Waterman 1960, Herreid 1980, Diaz \& Rosenberg 1995), little information is available on the physiological responses and tolerances of decapod larvae and early juvenile instars to reduced oxygen (but see Belman \& Childress 1974, Johnson \& Welsh 1985, Nakanishi 1987, Eriksson \& Baden 1997). For species possessing complex life histories, the probability of encountering hypoxic conditions may vary significantly between pelagic larval phases and post-settlement juvenile and adult (benthic) phases, which often occupy different habitats. Likewise, tolerance of low environmental oxygen may also vary among developmental stages, especially between larvae and newly metamorphosed benthic juveniles which may have different oxygen demands, sites of gas exchange, and compensatory mechanisms for responding to low oxygen conditions.

The blue crab Callinectes sapidus is a common inhabitant of estuaries and coastal areas along the Atlantic and Gulf of Mexico coasts of the USA (Williams 1984). While adult crabs occur primarily within estuaries, larvae are released near the entrance and are transported offshore to coastal waters where they undergo zoeal development before reinvading estuaries as postlarvae (megalopae) and migrating upstream toward nursery areas (see Epifanio 1995 for review). Up-estuary movement against strong net seaward flow is accomplished by means of selective tidal-stream transport, in which postlarval crabs are in the water column during rising tides at night and remain on or near the bottom at all other times (see Forward et al. 1995 for review). Megalopae then settle, metamorphose to the first-juvenile crab stage (J1), and undergo early juvenile development in beds of submerged aquatic vegetation and marsh-creek habitats (Orth \& van Montfrans 1987, Wilson et al. 1987, 1990, Lipcius et al. 1990, van Montfrans et al. 1991). Although it is unlikely that zoeal stages encounter hypoxic conditions in coastal waters, the ingress, settlement and early development of blue crab postlarvae and juveniles in estuarine habitats along the Atlantic and Gulf coasts coincides with seasonal hypoxic and anoxic events during the late summer and early fall fe.g. Officer et al. 1984, Pihl et al. 1991, Diaz et al. 1992, Howell \& Simpson 1994, Rabalais et al. 1994). Consequently, megalopae entering estuaries may encounter hypoxic or anoxic conditions (1) while migrating vertically toward bottom waters at the end of flood tide, (2) while located on or near the bottom during ebb tides, or (3) upon settlement and metamorphosis in shallow near-shore habitats, especially seagrass beds and tidal marshes. Thus, the physiological responses and tolerances of postlarval and early juvenile crabs to reduced oxygen conditions may have a significant impact on their migratory success, survivorship and growth, and may ultimately affect the structure and abundance of adult populations

The objectives of the present study were (1) to compare the rates of oxygen consumption $\left(V_{\mathrm{O}_{2}}\right)$ of postlarval and newly metamorphosed juvenile crabs under declining oxygen tensions, (2) to determine their scusitivity to short-term hypoxia and anoxia, (3) to correlate ontogenetic shifts in oxyregulation with changes in tolerance of hypoxia and anoxia, and (4) to determine the effect of exposure to hypoxia on the metamorphosis of megalopae to the first-juvenile crab (J1) stage. Results indicate that megalopae and $\mathrm{J} / \mathrm{crabs}$ are extremely sensitive to oxygen deficiency, with juveniles having a lower resistance to episodic hypoxia and anoxia than megalopae. Ontogenetic changes in the tolerance of crabs to low oxygen conditions were consistent with their respiratory responses to progressive hypoxia and suggest that low oxygen availability may be an important density-independent factor affecting the recruitment and survival of Callinectes sapidus megalopae and post-settlement juveniles. 


\section{MATERIALS AND METHODS}

Collection and maintenance. We collected Callinectes sapidus megalopae from July to October 1996 and 1997 in plankton tows $(0.67 \mathrm{~m}$ diameter nets; $500 \mu \mathrm{m}$ mesh) conducted during nocturnal flood tides near the entrance to the Newport River estuary (Beaufort, North Carolina, USA; $34^{\circ} 41^{\prime} \mathrm{N} ; 76^{\circ} 40^{\prime} \mathrm{W}$ ). Following collection, postlarvae were sorted by molt stage (Aiken 1973, Anger 1983, Stevenson 1985) and transferred to circular glass culture dishes $(9 \mathrm{~cm}$ diam.) containing filtered $(<5 \mu \mathrm{m})$ estuarine water ( 32 to $33 \mathrm{psu})$. To avoid the potential confounding effects of metamorphosis or molting on survivorship and oxygen consumption (Lewis \& Haefner 1976, Mangum et al. 1985), only megalopae determined to be in intermolt were used. Because early stage juvenile crabs are difficult to collect in the field, we maintained premolt postlarvae in circular glass culture dishes (50 to 100 crabs per dish) until metamorphosis ( 2 to 10 d). First-instar (J1) crabs were allowed to 'harden' for at least $48 \mathrm{~h}$ before they were used in experiments. Both megalopae and juvenile crabs were maintained in an environmental chamber (Sherer Model CEL4-4) at temperatures (24 to $25^{\circ} \mathrm{C}$ ) and light:dark cycles that were similar to ambient at the time of collection. Crabs were transferred daily to new water and fed newly hatched brine shrimp (Artemia spp.) nauplii.

Oxygen consumption. Oxygen consumption of postlarvae and newly metamorphosed juveniles was measured using a closed-system respirometer consisting of two $28 \mathrm{ml}$ glass chambers submerged in a refrigerated water bath. The top of each chamber was sealed with a rubber stopper, and the oxygen concentration of the chamber water was measured by inserting a polarographic oxygen sensor (Diamond General Mini-Oxygen Electrode Model No. 733) connected to a digital oxygen meter (Cameron Instrument $\mathrm{Co}$.) through a small hole in the stopper. Because of their small size relative to the volume of the respirometery chamber, it was necessary to measure oxygen uptake for groups of animals. For each trial, 20 megalopae or 10 first-instar juvenile crabs were placed in 1 of the 2 chambers filled with filtered $(<0.45 \mu \mathrm{m})$ estuarine water (32 psu). After a $1 \mathrm{~h}$ acclimation period, the chamber was sealed and the oxygen tension $\left(P_{\mathrm{O}_{2}}\right)$ of the water was recorded at 5 min intervals using an A/D converter (ComputerBoards CIO-DAS 16) and data acquisition software (Labtech Notebook Pro) attached to the output port of the meter. The second (control) chamber was filled with only filtered estuarine water and monitored simultaneously with an identical oxygen electrode and meter to control for sensor drift. During each trial, temperature was maintained at $25 \pm 0.1^{\circ} \mathrm{C}$. Trials continued until the oxygen tension in the experimental chamber dropped below $5 \%$ saturation $(-1 \mathrm{kPa})$. Trials were repeated 10 times using separate groups of newly collected megalopae and J1 crabs. Oxygen consumption rates $\left(V_{\mathrm{O}_{2}}\right.$ i $\mu \mathrm{O}_{2} \mathrm{~h}^{-1}$ ind. $\left.{ }^{-1}\right)$ were calculated from the rate of change in the $P_{\mathrm{O}_{2}}$ of the chamber water at intervals of $2 \mathrm{kPa}(\sim 10 \%$ air saturation). Since crabs remained undisturbed throughout the trial, rates of oxygen consumption were assumed to be equivalent to 'routine' levels.

Rates of oxygen consumption for megalopae and juveniles were compared using repeated measures analysis of variance (ANOVAR; Potvin et al. 1990). The relative degree of oxyconformity (oxygen consumption declines linearly with decreasing $P_{\mathrm{O}_{2}}$ ) or oxyregulation (oxygen consumption is maintained at a constant rate over a range of $\mathrm{P}_{\mathrm{O}_{2}}$ values) was evaluated by fitting the quadratic polynomial model to the data using the procedures outlined by Van Winkle \& Mangum (1975). The method uses the coefficient for the quadratic term $\left(\beta_{2}\right)$ as an index of the shape of the response curve. Oxyregulation is indicated by $\beta_{2}$ values significantly less than 0 , while coefficents not significantly different from 0 indicate oxyconformity (Van Winkle \& Mangum 1975). Similarly, the oxygen tension at which postlarval and juvenile crabs switch from oxygen-independent to oxygen-dependent respiration (i.e. critical oxygen tension, $P_{\text {ci }}$ Hill 1976) was determined by fitting a segmented quadratic model (with plateau) to the response curve using nonlinear (least squares) regression. The procedure estimates $P_{c}$ by fitting 2 models to the data that must meet at $P_{\mathrm{c}}$. At values above $P_{\mathrm{C}^{\prime}}$ the equation is constant (i.e. a horizontal line at the plateau, $V_{\mathrm{O}_{2}}=V_{\mathrm{O}_{2} \text { max }}$ ), but below $P_{c}$ the quadratic model $\left[V_{\mathrm{O}_{2}}=\beta_{0}+\beta_{1} P_{\mathrm{O}_{2}}+\beta_{2}\left(P_{\mathrm{O}_{2}}\right)^{2}\right]$ is fitted to the data All model parameters, including $V_{\mathrm{O}_{2} \max }$ and $P_{\mathrm{c}}$ were estimated iteratively using a modified Gauss-Newton method (SAS NLIN Procedure; SAS Institute 1990).

Tolerance of hypoxia and anoxia. We examined the effects of hypoxia and anoxia on the survival of postlarvae and $\mathrm{J} 1$ crabs by subjecting crabs to $P_{\mathrm{O}_{2}}$ values of $0.2 \mathrm{kPa}(<1 \%$ air saturation; considered anoxia for the purpose of this study), $2.05 \mathrm{kPa}(10 \%$ saturation), $4.12 \mathrm{kPa}$ (20\% saturation) and $20.53 \mathrm{kPa}$ (normoxic control). Treatment levels were selected based upon preliminary experiments that indicated megalopae and newly metamorphosed juvenile blue crabs are able to tolerate exposure to moderate hypoxia $(\geq 6.16 \mathrm{kPa}$; $-30 \%$ saturation) for several days. During each $24 \mathrm{~h}$ exposure period, crabs were placed individually in glass vials $(5.9 \mathrm{~cm} \times 2.7 \mathrm{~cm}$ diam.) containing $20 \mathrm{ml}$ of filtered $(<1 \mu \mathrm{m})$ estuarine water (32 psu). The tops of the vials were sealed with rubber stoppers, and target $P_{\mathrm{O}_{2}}$ values were obtained by equilibrating the water in the chambers with a mixture of $\mathrm{N}_{2}$ and compressed air delivered by stainless steel needles (18 gauge) inserted 
through small holes in the stopper. This method had no effect on the $\mathrm{pH}$ of the water in the vials during the exposure period. Oxygen saturation levels within the chambers were periodically checked using a YSI oxygen electrode and meter (Yellow Spring Instruments Model 57). Oxygen levels were consistently within $\pm 2 \%$ of target values in the hypoxia treatments and remained below the detection limit of the sensor in the anoxia treatment (i.e. $0.2 \mathrm{kPa}$ ).

At each oxygen tension $(100,20,10$ and $0 \%$ saturation), 60 megalopae and $54 \mathrm{~J} 1 \mathrm{crabs}$ were tested, and mortality was recorded at hourly intervals for the first $18 \mathrm{~h}$ and then $6 \mathrm{~h}$ later (total exposure time $=24 \mathrm{~h}$ ). Crabs were considered dead when their carapace turned opaque and they were inactive (legs retracted) and unresponsive to mechanical stimulation, even when transferred to normoxic conditions. Survival curves for postlarval and juvenile crabs were constructed using the product-limit method (i.e. Kaplan-Meier method; Kleinbaum 1996) and survival functions for each treatment group (i.e. oxygen tension) were compared using the Mantel log-rank test $\left(\chi^{2}\right.$ approximation; SYSTAT 7.0, SPSS Inc.). Since all megalopae and juvenile crabs subjected to normoxic conditions survived the $24 \mathrm{~h}$ exposure period (i.e. mortality was $0 \%$ ), control groups were not included in the analysis. Postlarval and juvenile crabs in the hypoxia and anoxia treatments that were alive at the end of the $24 \mathrm{~h}$ exposure period were treated as right-censored observations. Median survival times (i.e. time to $50 \%$ mortality; MST) for each treatment group were calculated from the survivorship functions using probit analysis (SAS PROBIT Procedure, SAS Institute 1990).

Recovery from short-term exposure to anoxia. Since anoxic conditions in deep water and shallow nearshore nursery habitats are often episodic and ephemeral, we examined the ability of megalopae and J1 crabs to survive and recover from short-term $(\leq 3 \mathrm{~h})$ exposure to anoxic conditions. Postlarvae and newly metamorphosed crabs were placed separately in glass vials $(5.9 \mathrm{~cm} \times 2.7 \mathrm{~cm}$ diam.) containing $20 \mathrm{ml}$ of deoxygenated water and exposed to anoxic conditions for 0 (normoxic controls), 1, 2, or $3 \mathrm{~h}$. At each treatment (exposure) level, 50 megalopae and J1 crabs were tested. Anoxic conditions were maintained during the exposure period by continuously bubbling $\mathrm{N}_{2}$ into chambers via a needle inserted through a rubber stopper sealing the top of the glass vial. The condition of crabs and postlarvae was determinod at 20 min intervals. Crabs were scored as being (1) alive (i.e. actively swimming or walking and responsive to mechanical simulation); (2) immobile (i.e. inactive and unable to swim or walk but occasionally responsive to mechanical simulation); or (3) dead (i.e. legs retracted, carapace opaque and unresponsive to mechanical simula- tion). At the end of the exposure period, active and immobile crabs were transferred to air-saturated water and their condition and recovery from anoxia was monitored at 20 min intervals for $4 \mathrm{~h}$.

Effect of hypoxia on metamorphosis. Two experiments were conducted to examine the effects of hypoxia on the time to metamorphosis (molting) of crabs from megalopae to the J1 stage. In the first, a cohort of megalopae was collected at the same time and transferred to glass vials containing $20 \mathrm{ml}$ of either hypoxic $\left(P_{\mathrm{O}_{2}}=8.21\right.$ or $12.32 \mathrm{kPa}[40$ or $60 \%$ saturation] $)$ or normoxic (100\% saturation) water and monitored every $6 \mathrm{~h}$ for metamorphosis. As in the previous experiments, oxygen tensions within the chambers were maintained at target $P_{\mathrm{O}_{2}}$ values by gently bubbling the water in the vials with mixtures of $\mathrm{N}_{2}$ /air delivered through needles inserted through the rubber stoppers sealing the tops of the vials. Megalopae were maintained at 24 to $25^{\circ} \mathrm{C}$ and transferred to new water and fed brine shrimp (Artemia spp.) nauplii daily.

Since oxygen levels in shallow areas often fluctuate throughout the day, the second experiment examined the possible effects of brief, daily exposure to hypoxic conditions on metamorphosis. The protocol was the same as for the previous experiment except megalopae were exposed to hypoxic conditions ( $20 \%$ saturation) for only 2 or 4 h each day. Hypoxic exposure occurred at the same time each day (14:00 to 18:00 h) and was initiated by transferring megalopae to new vials containing hypoxic $\left(P_{\mathrm{O}_{2}}=4.12 \mathrm{kPa}\right)$ water. At the end of each exposure period, postlarvae were returned to vials containing normoxic water. To avoid the potential confounding effects of disturbance and handling on metamorphosis, control animals were transferred to new vials containing normoxic water.

At each oxygen tension (Experiment 1, 40,60 and $100 \%$ saturation) or exposure period (Experiment 2: 0, 2 and $4 \mathrm{~h}$ ), 18 megalopae were tested, and each experiment was repeated 3 times with different cohorts (18 animals $/$ treatment/trial $\times 3$ trials $=54$ animals $/$ treat ment). Time to metamorphosis was determined to be the time interval (to the nearest $6 \mathrm{~h}$ ) between placement in the vials and molting. Comparisons of time to metamorphosis among treatments were made using failure-time analysis (Cox Proportional Hazards Model, SAS PHREG Procedure, SAS Institute 1990). Time to metamorphosis was the response of interest and was substituted for 'time until an event occurs' in the analysis (Muenchow 1986, Kleinbaum 1996). Thus, the 'hazard function' for each treatment group was the probability that a crab would metamorphose during the next time interval $(\Delta t)$, given that it had not metamorphosed since the experiment began (Muenchow 1986, Kleinbaum 1996). Experiments continued for up to $10 \mathrm{~d}$ and megalopae that died $(<1 \%)$ or failed to metamorphose 
by the end of the experiment were treated as rightcensored observations in the analysis. Since time to metamorphosis often varies significantly between megalopae collected at different times (Forward et al. 1996). cohort group was included as a covariate in the analysis. Thus, the Cox Model was used to calculate 'metamorphosis curves' (cumulative percent metamorphosis vs time) adjusted for the effects of cohort group for each treatment, and comparisons between hypoxia treatments and normoxic controls were made using a Wald $\left(\chi^{2}\right)$ test (Allison 1995).

\section{RESULTS}

\section{Oxygen consumption}

Oxygen consumption $\left(V_{\mathrm{O}_{2}}\right)$ of $\mathrm{J} 1$ crabs was significantly greater than that of megalopae at the same $P_{\mathrm{O}_{2}}$ (Fig. 1, Table 1). Although $V_{\mathrm{O}_{2}}$ for both groups declined significantly with progressive hypoxia (i.e. significant within subject effects; Table 1), the pattern of the response differed significantly between postlarval and newly metamorphosed crabs (i.e. significant $P_{\mathrm{O}_{2}} \times$ Stage interaction; Table 1). Examination of the first order polynomial contrasts indicated the linear trend accounted for most $(83.9 \%)$ of the variability across oxygen tensions (Table 1). Oxygen uptake rates for megalopae remained relatively constant $\left(V_{\mathrm{O}_{2} \max }=\right.$ $175.53 \mathrm{\mu lO}_{2} \mathrm{~h}^{-1}$ ind. ${ }^{-1}$ ) and independent of $P_{\mathrm{O}_{2}}$ at tensions above $\sim 43 \%$ saturation $\left(P_{\mathrm{c}}=8.88 \mathrm{kPa}\right.$; Fig. $\left.1 \mathrm{~A}\right)$. In contrast, juvenile crabs were only able to maintain maximum oxygen consumption $\left(V_{\mathrm{O}_{2} \max }=561.0 \mu \mathrm{l} \mathrm{O}_{2}\right.$ $\mathrm{h}^{-1}$ ind.- $\left.{ }^{-1}\right)$ at $P_{\mathrm{O}_{2}}>18.4 \mathrm{kPa}(89.6 \%$ saturation; Fig. $1 \mathrm{~B})$. The observed increase (3.1-fold) in $V_{\mathrm{O}_{2} \max }$ following metamorphosis cannot be attributed fully to size differences since $\mathrm{J} 1$ crabs are only $\sim 60 \%$ larger than mega-

Table 1. Callinectes sapidus. Results of repeated measures analysis of variance (ANOVAR) on the effect of developmental stage (Stage; megalopae vs first-instar crab) on the oxygen consumption $\left(V_{\mathrm{O}_{2}}\right)$. Results of first degree polynomial contrasts are presented to test for significant within-subjects (i.e. declining $P_{\mathrm{O}_{2}}$ ) effects

\begin{tabular}{|lrrrcc|}
\hline Source & df & $\mathrm{MS} \times 10^{4}$ & $F$ & $\mathrm{p}$ \\
\hline Between subjects & 1 & 377.18 & 99.30 & $<0.0001$ \\
$\quad$ Stage & 18 & 3.80 & & \\
$\quad$ Error & & & & \\
Within subjects & 9 & 13.77 & 39.78 & $<0.0001$ \\
$P_{\mathrm{O}_{2}}$ & 1 & 104.10 & 49.11 & $<0.0001$ \\
Linear & 9 & 6.11 & 17.65 & $<0.0001$ \\
$P_{\mathrm{O}_{2}} \times$ Stage interaction & 162 & 0.35 & & \\
$\quad$ Error & & & & & \\
\hline
\end{tabular}

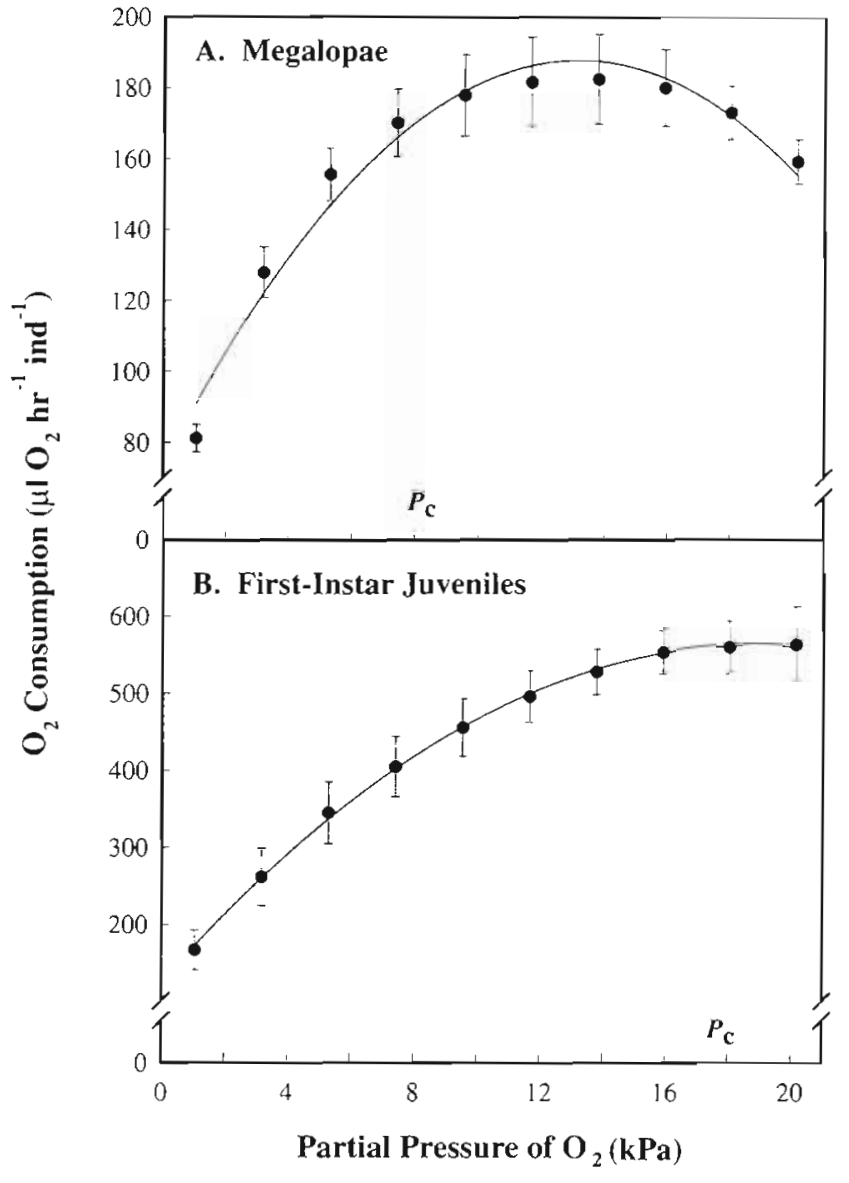

Fig. 1 Callinectes sapidus. Mean $( \pm \mathrm{SE})$ rates of oxygen consumption $\left(V_{\mathrm{O}_{2}}\right)$ of $(\mathrm{A})$ megalopae and (B) first-instar juvenile crabs as a function of water $P_{\mathrm{O}_{2}}(\mathrm{~N}=10)$. Oxygen uptake was measured at intervals of $2 \mathrm{kPa}$. Fit of the quadratic polynomial model is represented by the solid line. Vertical dashed line indicates the position of the critical oxygen tension $\left(P_{\mathrm{c}}\right)$

lopae (based on dry wt; Tankersley unpubl. data). Both $\mathrm{J} 1 \mathrm{crabs}$ and megalopae continued to consume oxygen at $P_{\mathrm{O}_{2}}=1 \mathrm{kPa}$ ( $\sim 5 \%$ saturation).

Analysis of the $V_{\mathrm{O}_{2}}$ response curves using the quadratic (i.e. second-degree polynomial) model technique described by Van Winkle \& Mangum (1975) revealed the same ontogenetic shift in the ability of newly metamorphosed J1 crabs to regulate aerobic metabolism. The quadratic model provided a good fit to the data for both groups (Fig. 1; megalopae: $R^{2}=0.97$; juveniles: $\left.R^{2}=0.99\right)$, but the value of the coefficient $\left(\beta_{2}\right)$ for the quadratic term was significantly less for megalopae than for juveniles $\left(-6.47 \times 10^{-5}\right.$ vs $-3.92 \times 10^{-5}$, respectively), indicating a greater degree of oxyregulation by megalopae at high oxygen tensions (Mangum \& Van Winkle 1973, Van Winkle \& Mangum 1975). Nevertheless, $\beta_{2}$ values for both groups were significantly less than 0 (megalopae: $t=-10.60, \mathrm{df}=7, \mathrm{p}<0.0001$; juveniles: $t=-27.66, \mathrm{df}=7, \mathrm{p}<0.0001)$. 


\section{Tolerance of hypoxia and anoxia}

Tolerance of anoxic and hypoxic conditions by postlarval and juvenile Callinectes sapidus was dependent upon developmental state, with $\mathrm{J} 1$ crabs experiencing greater mortality than megalopae at the same $P_{\mathrm{O}_{2}}$ level and exposure time (Fig. 2). No mortality occurred in megalopae and juveniles maintained in normoxic (control) conditions during the $24 \mathrm{~h}$ exposure period. Comparison of the survivorship curves for the hypoxia and anoxia treatments using a Mantel log-rank test indicated that mortality for both developmental stages increased significantly with decreasing $P_{\mathrm{O}_{2}}$ levels (Fig. 2: megalopae: $\chi^{2}=230.4, \mathrm{df}=2, \mathrm{p}<0.0001 ; \mathrm{J} 1$ crabs: $\chi^{2}=144.7$, $\mathrm{df}=2, \mathrm{p}<0.0001$ ). Although median survival times (MST) were consistently higher for megalopae than for juveniles (Table 2), neither group was able to tolerate anoxia for more than a few hours (Fig. 2, Table 2).

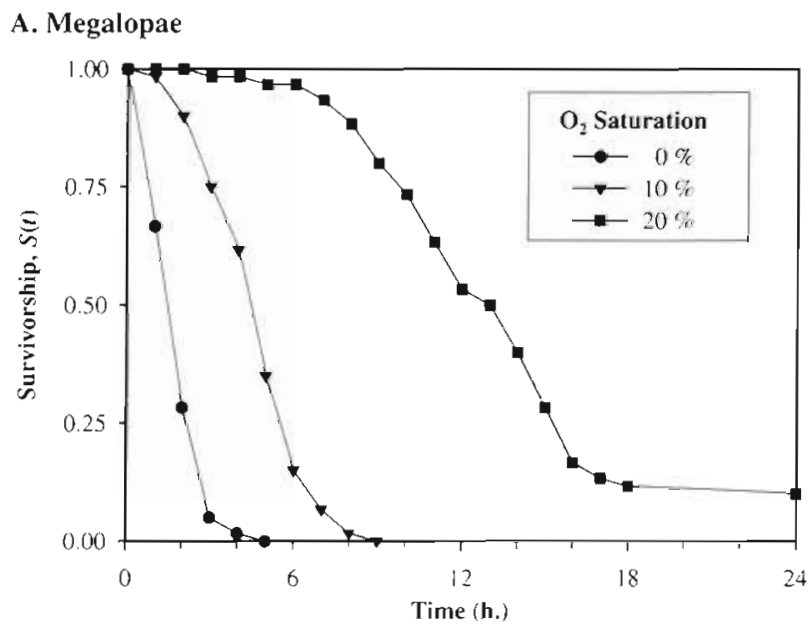

B. First-Instar Juveniles

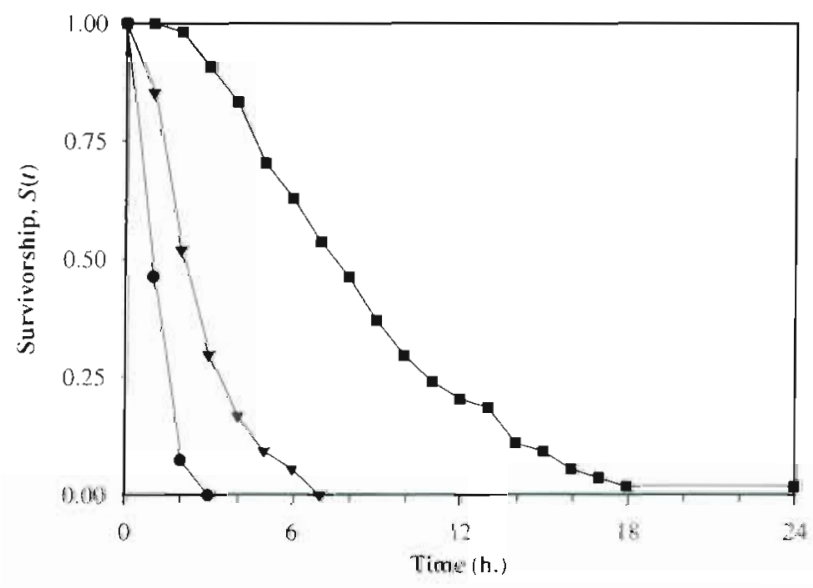

Fig. 2. Callinectes sapidus. Kaplan-Meier survivorship [S(t)] functions for (A) megalopae and (B) first-instar juvenile crabs subjected to continuous hypoxia (10 or $20 \%$ saturation) or anoxia ( $<1 \%$ saturation) for $24 \mathrm{~h}(\mathrm{~N}=60$ for megalopae and 54 for juveniles)
Table 2. Callinectes sapidus. Median survival times (h) for postlarvae and first-instar juveniles exposed to anoxic $(<1 \%$ saturation) and hypoxic (10 and 20\% saturation) conditions for $24 \mathrm{~h}$

\begin{tabular}{|c|c|c|c|}
\hline & $\begin{array}{c}<0.2 \mathrm{kPa} \\
10 \% \text { saturation) }\end{array}$ & $\begin{array}{l}\text { Oxygen tension } \\
2 \mathrm{kPa} \\
(10 \% \text { saturation })\end{array}$ & $\begin{array}{c}4 \mathrm{kPa} \\
(20 \% \text { saturation) }\end{array}$ \\
\hline Megalopae & 1.31 & 4.00 & 12.29 \\
\hline Juveniles (J1) & 0.99 & 2.07 & 7.17 \\
\hline
\end{tabular}

\section{Recovery from short-term exposure to anoxia}

As in the previous experiment, both postlarvae and first-instar crabs were unable to withstand short periods of anoxia, but mortality rates for juvenile crabs were consistently higher than for postlarvae. Nearly all (98\%) megalopae survived $1 \mathrm{~h}$ of anoxia (Fig. 3A), while only $48 \%$ of the first-stage crabs were able to tolerate the same period of exposure (Fig. 3D). After $2 \mathrm{~h}$ of anoxia, megalopae were either dead $(44 \%)$ or immobile (56\%) (Fig. 3B), while mortality for J1 crabs was nearly $100 \%$ (Fig. 3E). None of the first-instar crabs and only $7.5 \%$ of the postlarvae survived $3 \mathrm{~h}$ of anoxia (Fig. 3C \& F). Crabs which became immobile were moribund and typically died within $1 \mathrm{~h}$ if they were not transferred to normoxic water. Howcver, all megalopae and J1 crabs that survived the exposure period quickly recovered and survived for at least $4 \mathrm{~h}$ upon return to normoxia (Fig. 3).

\section{Effect of hypoxia on metamorphosis}

Both continuous and periodic (daily) exposure to hypoxia had a significant effect on the time to metamorphosis of crabs from megalopae to the first-instar stage. Under continuous hypoxia, time to metamorphosis increased significantly (Wald $\chi^{2}=17.77$, df $=1, \mathrm{p}<0.0001$; Fig. 4), but there was no significant difference between the times to metamorphosis of megalopae subjected to oxygen tensions of 40 and $60 \%$ saturation (Wald $x^{2}=$ 3.15, $\mathrm{df}=1, \mathrm{p}>0.05$; Fig. 4). Comparisons of the hazard ratios (risk ratios) revealed that megalopae maintained in normoxic conditions were 2.5 and 1.7 times more likely to metamorphose at any given time than those in the 40 and $60 \%$ oxygen saturation treatments, respectively.

Periodic (daily) exposure to hypoxia also had a significant effect on time to metamorphosis (Fig. 5). Metamorphosis was delayed for megalopae exposed to $20 \%$ oxygen-saturated sea water for $4 \mathrm{~h}$ each day compared to megalopae maintained under constant normoxia 
A. Megalopae: 1 h. Exposure

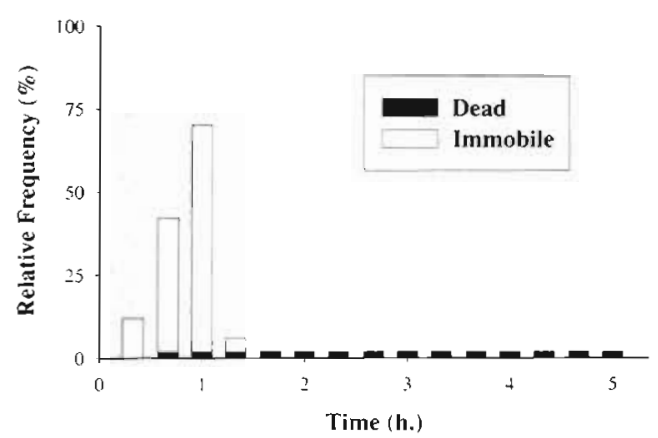

B. Megalopae: 2 h. Exposure

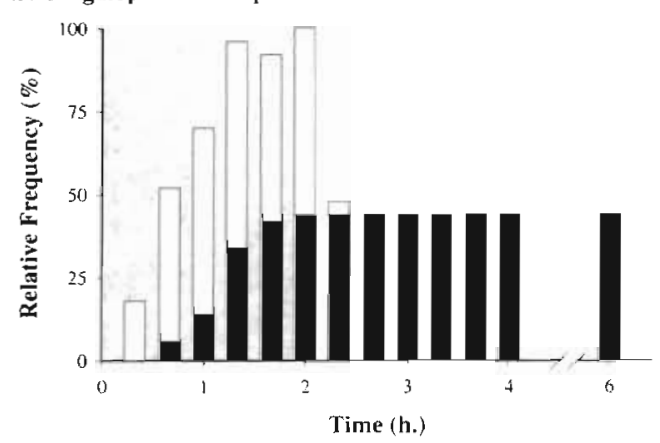

C. Megalopae: 3 h. Exposure

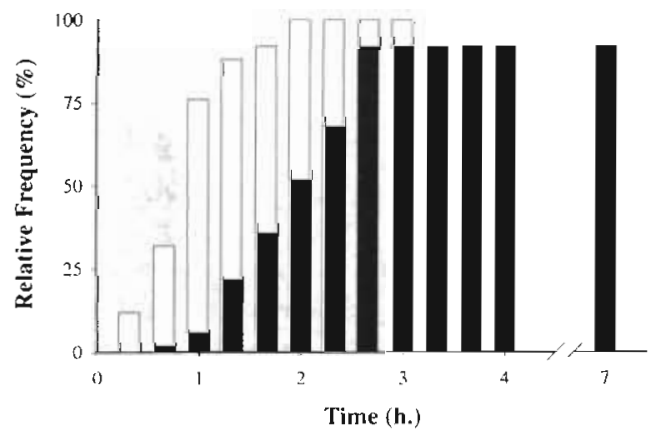

D. First-Instar Juveniles: 1 h. Exposure

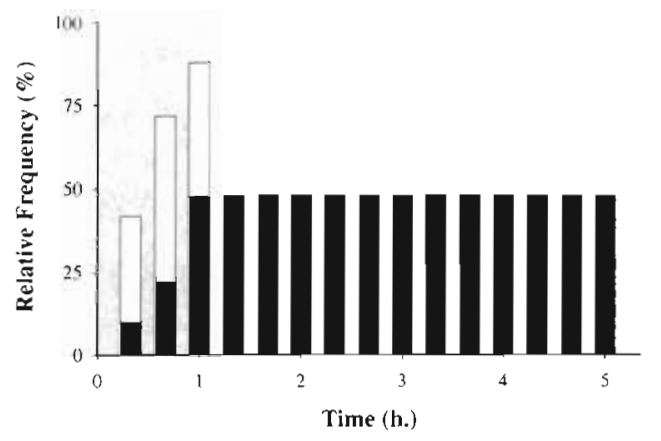

E. First-Instar Juveniles; 2 h. Exposure

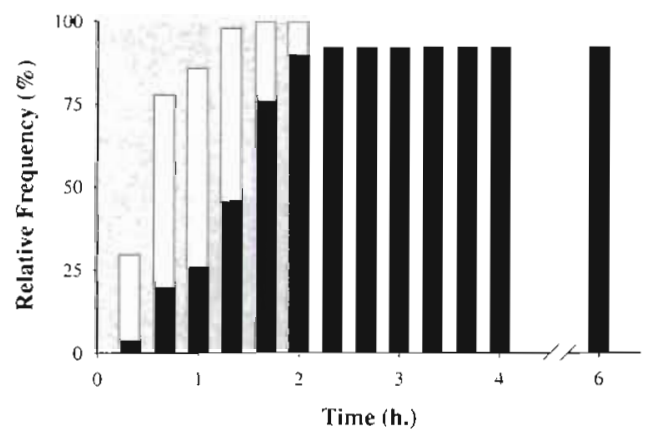

F. First-Instar Juveniles: 3 h. Exposure

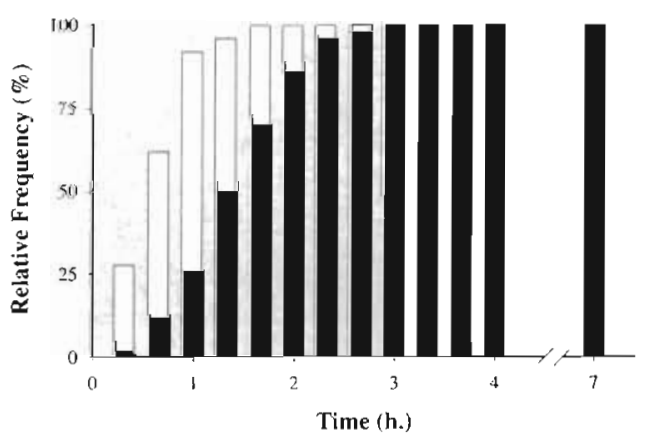

Fig. 3. Callinectes sapidus. Relative frequency (\%) of immobile (white bars) and dead (dark bars) megalopae (A to $C$ ) and newly metamorphosed juvenile crabs (D to $F$ ) following exposure to anoxic conditions for 1, 2, and $3 \mathrm{~h}$. Exposure period is indicated by the shaded region. Following exposure, megalopae and juveniles were returned to normoxia and their condition monitored for $4 \mathrm{~h}(\mathrm{~N}=50)$
(Wald $\chi^{2}=4.71, \mathrm{df}=1, \mathrm{p}<0.05$ ). Similarly, comparison of the hazard functions for the 2 treatments indicated that postlarvae in the normoxic controls were 1.54 times more likely to metamorphose at any given time than those in the $4 \mathrm{~h}$ hypoxia treatment. Although time to metamorphosis increased slightly in crabs exposed to hypoxic conditions for $2 \mathrm{~h}$ each day compared to the normoxic controls (Fig. 5), the difference was not statistically significant (Wald $\chi^{2}=1.74, \mathrm{df}=1, \mathrm{p}>0.05$ ).

\section{DISCUSSION}

Postlarval and juvenile Callinectes sapidus differed significantly in their tolerance of reduced oxygen and their ability to regulate oxygen-uptake under progressive hypoxia. Although megalopae were able to maintain aerobic metabolism at oxygen levels above
$8.88 \mathrm{kPa}(\sim 43 \%$ saturation; Fig. 1A), oxyregulation was greatly reduced following metamorphosis, with J1 crabs becoming oxydependent at tensions near saturation $\left(P_{c}=18.4 \mathrm{kPa} ; 90 \%\right.$ saturation; Fig. $\left.1 \mathrm{~B}\right)$. Although ontogenetic shifts in oxyregulatory ability have been reported for other decapods, the general trend is toward increased regulation with age. Zoeal and postlarval stages of the king crab Paralithodes camtschaticus remain oxyconformers throughout development, but early benthic juveniles show partial regulation following metamorphosis (Nakanishi 1987). Likewise, adult Norwegian lobster, Nephrops norvegicus have been reported to be better oxyregulators than the larvae (Spicer 1995). The oxyconformity exhibited by first-instar blue crabs (Fig. 1B) is not retained in older juvenile and adult crabs which possess a pattern that is remarkably similar to the one obtained for megalopae (Fig. 1A; Cameron 1989, Das \& Stickle 1993). There- 


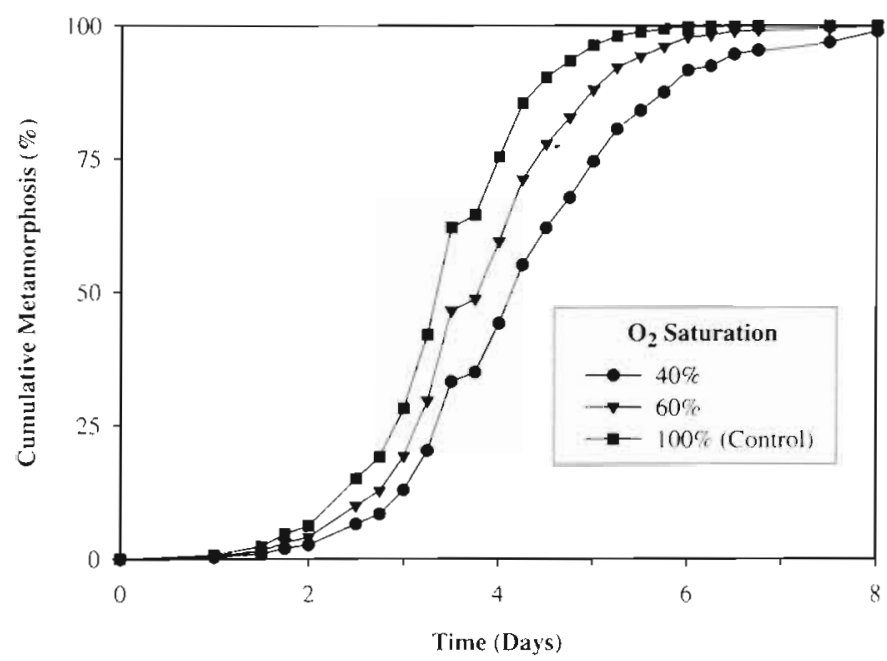

Fig. 4. Callinectes sapidus. Plot of cumulative percentage of metamorphosis of megalopae in estuarine water under continuous hypoxia ( 40 or $60 \%$ saturation) and normoxia (air-saturated control). Metamorphosis curves were calculated using the Cox Proportional Hazards Model $\{\mathrm{N}=54\}$

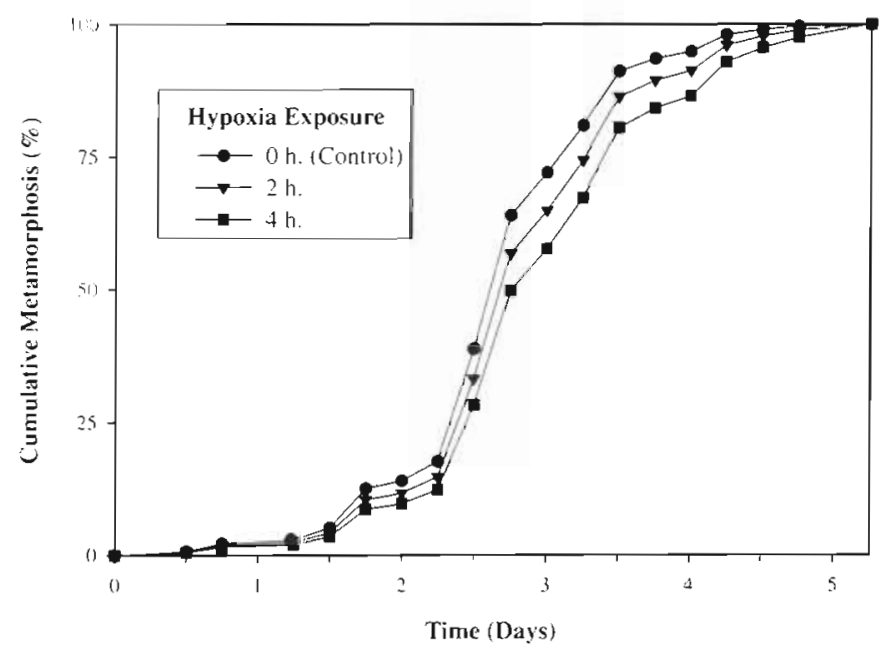

Fig. 5. Callinectes sapidus. Plot of cumulative percentage of metamorphosis of megalopae exposed to hypoxic conditions $(20 \%$ saturation) for 0 (continuous normoxia; control), 2 or $4 \mathrm{~h}$ each day. Following each exposure period, postlarvae were returned to normoxic (100\% air saturation) conditions. Metamorphosis curves were calculated using the Cox Proportional Hazards Model $(\mathbf{N}=54)$

fore, respiratory dependence is not a common physiological response to environmental hypoxia for most $C$. sapidus life-history stages and does not appear to be merely a consequence of the transition from a planktonic to benthic existence that accompanies metamorphosis. Additional observations of the aerobic metabolism of older instar juveniles during progressive hypoxia are needed to identify the stage at which oxyregulation improves during development.
Observed differences in the tolerances of megalopae and early benthic juveniles to hypoxic and anoxic conditions were consistent with the $V_{\mathrm{O}_{2}}$ data. Megalopae survived and metamorphosed under chronic exposure to oxygen tensions near or greater than their $P_{c}(\geq 40 \%$ saturation; Fig. 4), but died within a few hours when subjected to $P_{\mathrm{O}_{2}}$ values $\leq 4.12 \mathrm{kPa}$ ( $\leq 20 \%$ saturation; Table 2, Figs. 2 \& 3). First-instar crabs succumbed to the effects of anoxia faster than megalopae (Figs. 2 \& 3) and had shorter MSTs at all oxygen tensions (Table 2). However, these results conflict with previous studies of other invertebrate larvae and juveniles which indicate they become more tolerant of hypoxia as they get older (e.g. Widdows et al. 1989, Baker \& Mann 1992, Spicer 1995, Eriksson \& Baden 1997). Nevertheless, comparisons of the sensitivity of blue crab megalopae and $\mathrm{J} 1$ crabs with previous reports of hypoxia tolerance in older crabs indicate there is a general trend towards increased tolerance with age. Das \& Stickle (1993) reported juvenile Callinectes sapidus are very sensitive to chronic $\left(28\right.$ d) hypoxia, with a $\mathrm{LC}_{50}$ value of $69.4 \%$ saturation $\left(14.12 \mathrm{kPa}\right.$ ). Crabs exposed to $\mathrm{P}_{2}$ values of 0 and $3.33 \mathrm{kPa}(0$ and $16 \%$ saturation, respectively) died within $6 \mathrm{~d}$ of exposure, but most crabs survived at least $7 \mathrm{~d}$ at $P_{\mathrm{O}_{2}} \geq 6.67 \mathrm{kPa}$ ( $32 \%$ saturation). Comparative laboratory studies conducted by Stickle et al. (1989) yielded similar results but indicated that C. sapidus is less tolerant of hypoxic conditions than other estuarine crustaceans including the xanthid crabs Eurypanopeus depresus and Rhithropanopeus harrisil and the grass shrimp Palaemonetes pugio. Collectively these results suggest that (1) blue crabs, in general, are very sensitive to hypoxia; (2) tolerance increases with development from megalopa to adult; but (3) first-instar juveniles deviate from this pattern and are more vulnerable to hypoxia, most likely as a result of rapid anatomical or physiological changes that occur during metamorphosis.

In the current study, tolerance of hypoxia and anoxia was measured using intermolt (Stage C) megalopae and J1 crabs. Consequently, our results most likely underestimate the sensitivity of newly metamorphosed crabs to reduced oxygen conditions since hypoxia toleranco is expected to decrease during metamorphosis. In adult blue crabs, molting is a stressful, energydemanding process that is accompanied by changes in the performance of the cardiovascular and ventilatory systems, including blood gas tensions, acid-base balance and oxygen-transport properties (deFur et al. 1985, Mangum 1985, Mangum et al. 1985, Cameron 1989). Decreased net synthesis of the oxygen-carrying protein hemocyanin ( $\mathrm{Hc}$ ) and water uptake prior to ecdysis causes Hc levels to decline more than 4 -fold in postmolt crabs (Mangum et al. 1985). Ventilation also decreases briefly during and immediately following 
exuviation as the scaphognathite hardens (deFur et al. 1985). Although it is unknown whether the respiratory and cardiovascular systems of megalopae undergo similar changes during metamorphosis, it is safe to assume that the mechanisms for oxygen transport are perturbed during ecdysis and the chances of surviving hypoxia stress and other adverse environmental conditions are severely reduced.

Metabolic regulation and $P_{\mathrm{c}}$ have been reported to vary with environmental conditions and physiological state of the animal, including temperature, salinity, activity, molt cycle, time of day, circulation and availability of respiratory structures (for reviews see Herreid 1980, McMahon \& Wilkens 1983). Since the experimental procedures and conditions used to quantify respiratory response and sensitivity to hypoxia and anoxia were identical for postlarvae and juveniles, the observed differences in the ability of post-settlement crabs to regulate oxygen-uptake and tolerate hypoxia and anoxia are most likely the result of ontogenetic changes in the respiratory and cardiovascular systems and the compensatory mechanisms available for coping with reduced oxygen. In adult blue crabs, oxygen supply is maintained under moderate hypoxia by increasing ventilation through increased scaphognathite activity, while stroke volume and extraction efficiency remain constant (Batterton \& Cameron 1978). Prolonged hypoxic (sublethal) exposure results in structural changes in blue crab Hc, which increases its oxygen affinity, thereby enhancing blood oxygenation at the gill (deFur et al. 1990, Mangum 1997). The structure of crustacean Hc also often changes with ontogeny (see Terwilliger 1998 for review) and larvae of several decapod species have been shown to possess an Hc with a lower oxygen-affinity than adult Hc (Terwilliger et al. 1986, Olsen et al. 1990, Terwilliger \& Brown 1993, Spicer 1995, Brown \& Terwilliger 1998). Similar developmental changes in the site of gas exchange and the concentration, structure and function of Hc may impose constraints on oxygen transport in $\mathrm{J} 1$ crabs and may explain, at least in part, the observed shift in the respiratory responses of megalopae and first-instar crabs to hypoxia.

Metamorphosis of blue crab megalopae to the J1 crab stage occurs within estuaries following development in offshore coastal/oceanic areas. Recent studies indicate that the duration of the megalopal stage, and therefore the rate of development, is influenced by the presence of chemical cues from estuaries and known settlement habitats. Metamorphosis is delayed in offshore water (Forward et al. 1994, 1996, 1997, Wolcott \& DeVries 1994 ) but is accelerated by exposure to estuarine (Forward et al. 1994, 1996) and lower salinity water (Forward et al. 1994), and odors from seagrasses (Forward et al. 1994, 1996), marsh cord grass (Forward et al.
1996), humic acids (Forward et al. 1997) and some macroalgae (Brumbaugh \& McConaugha 1995, Forward et al. 1996). Similar cues from settlement habitats, including estuarine sediment and adult odor, accelerate metamorphosis in other brachyuran crabs including Uca spp. (Christy 1989, O'Connor 1991, O'Connor \& Judge 1997), Panopeus herbstii (Weber \& Epifanio 1996) and Rhithropanopeus harrisii (Fitzgerald et al. 1998). At normal temperature and salinities, the only chemical cue known to reverse the effects of stimulatory cues and increase the time to metamorphosis is ammonium (Forward et al. 1997). Our results indicate that the metamorphosis-accelerating effects of estuarine water are also reversed by exposure to chronic and intermittent hypoxia (Figs. 4 \& 5). Constant sublethal hypoxia has previously been found to have a similar effect on the molting rate of later-stage juvenile Callinectes sapidus (Das \& Stickle 1993). Since ammonium levels in the field are inversely related to oxygen levels (Fitt \& Coon 1992), their combined effects may further inhibit metamorphosis. Thus, the effects of hypoxia on metamorphosis are consistent with the hypothesis that conditions in suboptimal settlement habitats inhibit estuarine cues which accelerate metamorphosis, presumably delaying settlement so that megalopae have time to locate other more suitable substrates.

It is well known that marine planktonic larvae use physical and chemical cues in settlement site recognition and settlement (for reviews see Crisp 1984, Pawlik 1992, Rittschof et al. 1998). Recent field studies indicate that blue crab megalopae can distinguish among possible settlement sites using chemical cues (Welch et al. 1997). Thus, high densities of megalopae and earlyinstar blue crabs in vegetative habitats, such as seagrass beds and tidal marshes (Orth \& van Montfrans 1987, Mense \& Wenner 1989, Lipcius et al. 1990, Wilson et al. 1990, van Montfrans et al. 1991, Morgan et al. 1996), are probably the result of differences in postsettlement mortality and emigration among habitats as well as active selection or rejection of potential vegetative or unvegetative habitats based upon chemical cues (Welch et al. 1997). Since habitats experiencing both long-term and periodic hypoxia would be physiologically stressful or lethal to megalopae and postmetamorphic crabs, differences in their distribution among habitats may reflect active avoidance of oxygendepleted water in shallow areas as well as increased mortality in areas prone to seasonal or diel occurrences of hypoxia. Likewise, habitat avoidance and post-settlement mortality may depend upon multiple negative cues or abiotic factors that typically co-occur in areas of reduced oxygen, such as salinity, hypercapnia and the presence of sulfide, which may be more toxic or effective negative cues when combined with hypoxia than hypoxia alone (Diaz \& Rosenberg 1995). 
In addition to affecting habitat selection, behavioral responses for avoiding hypoxic bottom water (e.g. increased activity or negative geotaxis) may also interfere with the flood-tide transport behavior of crab megalopae during shoreward migration to settlement habitats by (1) serving as a physical barrier to vertical migration and preventing crabs from reaching the substrate and exiting the water column at the end of flood tide or (2) inducing crabs to reenter the water column at the incorrect phase of the tide. Both scenarios would reduce recruitment success by increasing the likelihood that crabs are transported seaward by ebb currents. Behavioral avoidance of lethal and sublethal bottom water has been documented for a variety of benthic invertebrates and fish (e.g. May 1973, Harper et al. 1981, Baden et al. 1990, Petersen \& Petersen 1990, Pihl et al. 1991, Breitburg 1994, Howell \& Simpson 1994, Nilsson \& Rosenberg 1994). Field studies examining the effect of reduced oxygen conditions on the vertical distribution of adult Callinectes sapidus indicate they avoid hypoxic bottom water by migrating to shallower areas (Pihl et al. 1991, Diaz et al. 1992). However, laboratory assays suggest the ability of juvenile blue crabs to detect and avoid such conditions may be limited (Das \& Stickle 1994). Experiments are currently underway to evaluate the behavioral responses of postlarvae and early-instar juvenile blue crabs to hypoxia in order to determine its potential influence on up-estuary transport, habitat selection and settlement.

Previous studies of the effects of hypoxia on the physiology, behavior and population dynamics of Callinectes sapidus have not included postlarval and early juvenile stages. Moreover, studies examining the population dynamics of early benthic stage crabs have focused on factors influencing the availability of postlarvae among habitats (Olmi et al. 1990, Morgan et al. 1996) and the contribution of density-dependent processes to observed patterns in habitat use (Wilson et al. 1987, 1990, Mense \& Wenner 1989, Heck \& Coen 1995, Morgan et al. 1996. Pile et al. 1996, Moksnes et al. 1997). The present study indicates that reduced oxygen conditions may be an important density-independent (abiotic) factor regulating the supply of postlarvae and survivorship of post-settlement crabs. This suggests, together with the ability of megalopae to select among potential habitats, that the recruitment of megalopae may be significantly impacted by variation in the distribution and severity of hypoxic water in vegetative areas. Since blue crab megalopae and juveniles depend upon habitat refugia, additional field studies are needed to determine the extent to which hypoxia limits the availability or relative value of nursery and refuge habitats, and its impact, either direct or indirect, on important post-settlement processes such as predation, competition and emigration.
Acknowledgements. We are grateful to R. B. Forward, Jr for support, input, and use of facilities and equipment at DUML. Thanks are also due to D. Blondel, T P. Fitzgerald, K. A. Kachurak, M. A. Sigala and J. M. Welch for help with the collection and maintenance of postlarval crabs. R. V. Dimock, Jr. R. B. Forward, $J$ and $V$. Kennedy provided useful comments and suggestions on earlier drafts of the manuscript. Financial support was provided by National Science Foundation Grant OCE-9819355/9901146 and a project development grant from Maryland Sea Grant College. M.G.W. was supported by a Graduate Research Fellowship from UMBC.

\section{LITERATURE CITED}

Aiken DE (1973) Proecdysis, setal development, and molt prediction in the American lobster (Homarus americanus). J Fish Res Board Can 30:1337-1344

Allison PD (1995) Survival analysis using the SAS system. SAS Institute Inc., Cary, NC

Amberson WR, Mayerson HA, Scott WJ (1924) The influence of oxygen tension upon metabolic rate in invertebrates. J Gen Physiol 7:171-176

Anger K (1983) Moult cycle and metamorphosis in Hyas araneus larvae (Decapoda, Majidae), reared in the laboratory. Helgol Meeresunters 36:285-302

Asmus RM, Asmus H, Wille A, Zubillaga GF, Reise K (1994) Complementary oxygen and nutrient fluxes in seagrass and mussel banks? In: Dyer KR, Orth RJ (eds) Changes in fluxes in estuaries: implications from sriences to management. Olsen and Olsen, Fredensborg, p $227-237$

Baden SP, Loo LO, Pih] L, Rosenberg R (1990) Effects of eutrophication on benthic communities including fish: Swedish west coast. Ambio 19:113-122

Baker SM, Mann R (1992) Effects of hypoxia and anoxia on larval settlement, juvenile growth, and juvenule survival of the oyster Crassostrea virginica. Biol Bull 182:263-269

Batterton CV, Cameron JN (1978) Characteristics of resting ventilation and response to hypoxia, hypercapnia, and emersion in the blue crab Callinectes sapidus (Rathbun) J Exp Zool 203:403-418

Belman BW, Childress HJ (1974) Oxygen consumption of the larvae of the lobster Panulirus interruptus (Randall) and the crab Cancer productus Randall. Comp Biochem Physiol 44A:821-828

Breitburg DL (1990) Near-shore hypoxia in the Chesapeake Bay: patterns and relationships among physical factors. Estuar Coast Shelf Sc1 30:593-609

Breitburg DL (1994) Behavioral response of fish larvae to low dissolved oxygen concentrations in a stratified water column. Mar Biol 120:615-625

Breitburg DL, Steinberg N, DuBeau S, Cooksey C, Houde ED (1994) Effects of low dissolved oxygen on predation on estuarine fish larvae. Mar Ecol Prog Ser 104:235-246

Breitburg DL, Loher T, Pacey CA, Gerstein A (1997) Varying effects of low dissolved oxygen on trophic interactions in an estuary food web. Ecol Monogr 67:489-507

Brown AC, Terwilliger NB (1998) Ontogeny of hemocyanin function in the dungeness crab Cancer magister: hemolymph rodulation of hemocyanin oxygen-binding. J Exp Biol 201:819-826

Brumbaugh RD, McConaugha JR (1995) Time to metamorphosis of blue crab Callinectes sapidus megalopae: effects of benthic macroalgae. Mar Ecol Prog Ser 129:1 i3-118

Cameron JN (1989) The respiratory physiology of animals. Oxford University Press, New York

Carpenter JH, Cargo DG (1957) Oxygen requirement and 
mortality of the blue crab in the Chesapeake Bay. Tech Report 13, Chesapeake Bay Inst., Johns Hopkins Univ., Baltimore, MD, p 22

Christy JH (1989) Rapid development of megalopae of the fiddler crab Uca pugilator reared over sediment: implications for models of larval recruitment. Mar Ecol Prog Ser 57 : $259-265$

Cochran RE, Burnett LE (1996) Respiratory responses of the salt marsh animals, Fundulus heteroclitus, Leiostomus xanthurus, and Palaemonetes pugio to environmental hypoxia and hypercapnia and to the organophosphate pesticide, azinphosmethyl. J Exp Mar Biol Ecol 195:125-144

Crisp DJ (1984) Overview of research on marine invertebrate larvae 1940-1980. In: Costlow JD, Tepper RC (eds) Marine biodeterioration. Naval Institute Press, Annapolis, MD, p $103-126$

Das T, Stickle WB (1993) Sensitivity of crabs Callinectes sapidus and $C$. similis and the gastropod Stramonita haemastoma to hypoxia and anoxia. Mar Ecol Prog Ser 98: $263-274$

Das T, Stickle WB (1994) Detection and avoidance of hypoxic water by juvenile Callinectes sapidus and $C$. similis. Mar Biol 120:593-600

deFur PL, Mangum CP, MCMahon BR (1985) Cardiovascular and ventilatory changes during ecdysis in the blue crab Callinectes sapidus Rathbun. J Crustac Biol 5:207-215

deFur PL, Mangum CP, Reese JE (1990) Respiratory responses of the blue crab Callinectes sapidus to long-term hypoxia. Biol Bull 178:46-54

Diaz RJ, Rosenberg R (1995) Marine benthic hypoxia: a review of its ecological effects and the behavioral responses of benthic macrofauna. Oceanogr Mar Biol Annu Rev 33:245-303

Diaz RJ, Neubauer RJ, Schaffner LC, Pihl L, Baden SP (1992) Continuous monitoring of dissolved oxygen in an estuary experiencing periodic hypoxia and the effect of hypoxia on macrobenthos and fish. Mar Coast Eutroph 1992: $1055-1068$

Epifanio CE (1995) Transport of blue crab (Callinectes sapidus) larvae in the waters off Mid-Atlantic states. Bull Mar Sci 57:713-725

Eriksson SP, Baden SP (1997) Behaviour and tolerance to hypoxia in juvenile Norway lobster (Nephrops norvegicus) of different ages, Mar Biol 128:49-54

Falkowski PG, Hopkins TS, Walsh JJ (1980) An analysis of factors affecting oxygen depletion in the New York Bight. J Mar Res 38:479-506

Fitt WK, Coon SL (1992) Evidence for ammonia as a natural cue for recruitment of oyster larvae to oyster beds in a Georgia salt marsh. Biol Bull 182:401-408

Fitzgerald TP, Forward RB Jr, Tankersley RA (1998) Metamorphosis of the estuarine crab Rhithropanopeus harrisii (Gould): effect of water type and adult odor. Mar Ecol Prog Ser 165:217-223

Forward RB Jr, Frankel DAZ, Rittschof D (1994) Molting of megalopae from the blue crab Callinectes sapidus: effects of offshore and estuarine cues. Mar Ecol Prog Ser 113: $55-59$

Forward RB Jr, Tankersley RA, De Vries MC, Rittschof D (1995) Sensory physiology and behavior of blue crab (Callinectes sapidus) postlarvae during horizontal transport. Mar Freshw Behav Physiol 26:233-248

Forward RB Jr, DeVries MC, Rittschof D, Frankel DAZ, Bischoff JP, Fisher CM. Welch JM (1996) Effects of environmental cues on metamorphosis of the blue crab Callinectes sapidus. Mar Ecol Prog Ser 131:165-177

Forward RB Jr, Tankersley RA, Blondel D, Rittschof D (1997)
Metamorphosis of the blue crab Callinectes sapidus: effects of humic acids and ammonium. Mar Ecol Prog Ser $57: 277-286$

Gaston GR (1985) Effects of hypoxia on macrobenthos of the inner shelf off Cameron, Louisiana. Estuar Coast Shelf Sci 20:603-613

Grieshaber MK, Hardewig I, Kreutzer U, Pörtner HO (1994) Physiological and metabolic responses to hypoxia in invertebrates. Rev Physiol Biochem Pharmacol 125:44-147

Harper DE, McKinney LD, Salzer RR, Case RJ (1981) The occurrence of hypoxic bottom water off the upper Texas coast and its effect on the benthic biota. Contrib Mar Sci $24: 53-79$

Heck KL Jr, Coen LD (1995) Predation and abundance of juvenile blue crabs: a comparison of selected east coast and Gulf coast (USA) studies. Bull Mar Sci 57:877-883

Herreid CF II (1980) Review: hypoxia in invertebrates. Comp Biochem Physiol 67A:311-320

Hill RW (1976) Comparative physiology of animals: an environmental approach. Harper and Row, New York

Howell P, Simpson D (1994) Abundance of marine resources in relation to dissolved oxygen in Long Island Sound. Estuaries 17:394-402

Johnson DA, Welsh BL (1985) Detrimental effects of Ulva lactuca (L.) exudates and low oxygen on estuarine crab larvae. J Exp Mar Biol Ecol 86:73-83

Kenney BE, Litaker W, Duke CS, Ramus J (1988) Community oxygen metabolism in a shallow tidal estuary. Est Coast Shelf Sci 27:33-43

Kleinbaum DG (1996) Survival analysis: a self-learning text Springer, New York

Kuo AY, Neilson BJ (1987) Hypaxia and salinity in Virginia estuaries. Estuaries 10:277-283

Lewis EG, Haefner PA (1976) Oxygen consumption of the blue crab, Callinectes sapidus Rathbun, from proecdysis to postecdysis. Comp Biochem Physiol 54A:55-60

Lipcius RN, Olmi EJ III, van Montfrans J (1990) Regulatory mechanisms of postlarval blue crab recruitment: settlement, metamorphosis and developmental state. Bull Mar Sci $46: 247$

Llansó RJ (1992) Effects of hypoxia on estuarine benthos: the Lower Rappahannock River (Chesapeake Bay), a case study. Estuar Coast Shelf Sci 35:491-515

Mangum CP (1985) Molting in the blue crab, Callinectes sapidus: a collaborative study of intermediary metabolism, respiration and cardiovascular function, and ion transport. J Crustac Biol 5:185-187

Mangum CP (1997) Adaptation of the oxygen transport system to hypoxia in the blue crab, Callinectes sapidus. Am Zool 37:604-611

Mangum CP, Towle D (1977) Physiological adaptation to unstable environments. Am Sci 65:67-75

Mangum C, Van Winkle W (1973) Responses of aquatic invertebrates to declining oxygen conditions. Am Zool 13: $529-541$

Mangum CP, McMahon BR, deFur PL, Wheatly MG (1985) Gas exchange, acid-base balance, and the oxygen supply to the tissues during a molt of the blue crab Callinectes sapidus. J Crustac Biol 5:188-206

May EB (1973) Extensive oxygen depletion in Mobile Bay, Alabama. Limnol Oceanogr 18:353-366

McMahon BR, Wilkens JL (1983) Ventilation, perfusion, and oxygen uptake. In: Mantel LH (ed) The biology of the Crustacea, Vol. 5. Internal anatomy and physiological regulation. Academic Press, New York, p 289-372

Mense DJ, Wenner EL (1989) Distribution and abundance of early life history stages of the blue crab, Callinectes 
sapidus, in tidal marsh creeks near Charleston, South Carolina. Estuaries 12:157-168

Moksnes PO, Lipcius RN, Pihl L, van Montfrans J (1997) Cannibal-prey dynamics in young juveniles and postlarvae of the blue crab. J Exp Mar Biol Ecol 215:157-187

Morgan SG, Zimmer-Faust RK, Heck KL Jr, Coen LD (1996) Population regulation of blue crabs Callinectes sapidus in the northern Gulf of Mexico: postlarval supply. Mar Ecol Prog Ser 133:73-88

Muenchow G (1986) Ecological use of failure time analysis Ecology 67:246-250

Nakanishi T (1987) Effects of water temperature and hypoxia on the oxygen consumption of larvae and post-larvae of king crab. Nippon Suisan Gakkaishi 53:235-237

Nilsson HC, Rosenberg R (1994) Hypoxic response of two marine benthic communities. Mar Ecol Prog Ser 115 209-217

O'Connor $N J^{\prime}$ (1991) Flexibility in timing of the metamorphic molt by fiddler crab megalopae Uca pugilator. Mar Ecol Prog Ser 68:243-247

O'Connor NJ, Judge ML (1997) Flexibility in timing of molting of fiddler crab megalopae: evidence of in situ manipulation of cues. Mar Ecol Prog Ser 146:55-60

Officer CB, Biggs RB, Taft JL, Cronin LE, Tyler ME, Boyton WR (1984) Chesapeake Bay anoxia: origin, development, and significance. Science 223:567-590

Olmi EL III, van Montfrans J, Lipcius RN, Orth RJ, Sadler PW (1990) Variation in planktonic availability and settlement of blue crab megalopae in the York. River, Virginia. Bull Mar Sci 46:230-243

Olsen K, Taylor AC, Capuzzo JM (1990) Correlation between hemocyanin structure and function in American lobsters Am Zool 30:94 (abstract)

Orth RJ, van Montfrans J (1987) Utilization of a seagrass meadow and tidal marsh creek by blue crabs Callinectes sapidus. I. Seasonal and annual variations in abundanice with emphasis on post-settlement juveniles. Mar Ecol Prog Ser 41:283-294

Orth RJ, van Montfrans J (1990) Utilization of marsh and seagrass habitats by early stages of Callinectes sapidus: a latitudinal perspective. Bull Mar Sci 46:126-144

Pawlik JR (1992) Induction of marine invertebrate larval settlement: evidence for chemical cues. In: Paul VJ (ed) Ecological roles of marine natural products. Cornell University Press, New York, p 189-236

Peterson JK, Peterson GI (1990) Tolerance, behaviour and oxygen consumption in the sand goby, Pomatoschistus minutus (Pallas), exposed to hypoxia. J Fish Biol 37:921-933

Pihl L. Baden SP, Diaz RJ (1991) Effects of periodic hypoxia on distribution of demersal tish and crustaceans. Mar Biol 108:349-360

Pihl L, Baden SP, Diaz RJ, Schaffner LC (1992) Hypoxiainduced structural changes in the diet of bottom-feeding fish and Ciustacea. Mar Biol 112:349-361

Pile A, Lipcius R, van Montfrans J, Orth R (1996) Densitydependent settler-recruit-juverile relationships in blue crabs. Ecol Monogr 66:277-300

Potvin C, Lechowicz MJ, Tardif S (1990) The statistical analysis of ecophysiological response curves obtained from experiments involving repeated measures. Ecology 71 $1389-1400$

Poulin R, Wolf NG, Kramer DL [1987) The effect of hypoxia on the vulnerability of guppies (Poecilia reticulata, PoeciliIdae) to an aquatic predator (Astronotus ocellatus, Cichlidae). Environ Biol Fishes 20:285-292

Rabalais NN, Wiseman WJ Jr, Turner RE (1994) Comparison of continuous records of near-bottom dissolved oxygen from the hypoxia zone along the Louisiana coast. Estuaries 17:850-861

Rahel F, Kolar C (1990) Trade-offs in the response of mayflies to low oxygen and fish predation. Oecologia 84:39-44

Rittschof D, Forward RB Jr, Cannon G, Welch JM, McClary M, Holm ER, Clare AS, Conova S, McKelvey LM, Bryan P. Van Dover CL (1998) Cues and context: larval responses to physical and chemical cues. Biofouling 12:31-44

Rosenberg R, Loo LO (1988) Marine eutrophication induced oxygen deficiency: effects on soft bottom fauna, Western Sweden. Ophelia 29:213-225

Rosenberg R, Elmgren R, Fleischer S, Jonsson P, Persson G, Dahlin $H$ (1990) Marine eutrophication case studies in Sweden: a synopsis. Ambio 19:102-108

Ruiz GM, Hines AH, Posey MH (1993) Shallow water as a refuge habitat for fish and crustaceans in non-vegetated estuaries: an example from Chesapeake Bay. Mar Ecol Prog Ser 99:1-16

Sanford LP, Sellner KG, Breitburg DL (1990) Covariability of dissolved oxygen with physical processes in the summertime Chesapeake Bay. J Mar Res 48:567-590

Santos SL, Simon JL (1980) Response of soft-bottom benthos to annual catastrophic disturbance in a south Florida estuary. Mar Ecol Prog Ser 3:347-355

SAS Institute (1990) SAS/STAT user's quide, Version 6. SAS Institute Inc, Cary, NC

Sogard SM, Able KW (1991) A comparision of eelgrass, sealettuce macroalgae, and marsh creeks as habitats for epibenthic fishes and decapods. Estuar Coast Shelf Sci 33:501-519

Spicer JI (1995) Ontogeny of respiratory function in crustaceans exhibiting either direct or indirect development. J Exp Zool 272:413-418

Steimle FW, Sindermann CJ (1978) Review of oxygen depletion and associated mass mortalitins of shellfish in the Middle Atlantic Bight in 1976. Mar Hish Rev 40:17 26

Stevenson JR (1985) Dynamics of the integument. In: Bliss DE (ed) The biology of Crustacea, Vol 9 . Integument, pigments, and hormonal processes. Academic Press, New York, p 1-42

Stickle WB, Kapper MA, Liu LL, Gnaiger E, Wang SY (1989) Metabolic adaptations of several species of crustaceans and molluscs to hypoxia: tolerance and microcilormetric studies. Biol Bull 177:303-312

Taylor EW (1982) Control and co-ordindtion of ventilation and circulation in crustaceans: response to hypoxia and exercise. J Exp Biol 100:289-319

Terwilliger NB (1998) Functional adaptations of oxygentransport proteins. J Exp Biol 201:1085-1098

Terwilliger NB, Brown AC (1993) Ontogeny of hemocyanin function in the Dungeness crab Cancer magister. the interactive effects of developmental stage and divalent cations on hemocyanin oxygenation properties. J Exp Biol $183: 1-13$

Terwilliger NB, Terwilliger RC, Graham R (1986) Crab hemocyanin function changes during development. In: Linzen $B$ (ed) Invertebrate oxygen carriers. Springer-Verlag, Berlin, p 333-335

van Montfrans J, Ryer CH, Orth RJ (1991) Population dynamics of blue crabs Callinectes sapidus Rathbun in a lower Chesapeake Bay tidal marsh creek. J Exp Mar Biol Ecol 153:1-14

Van Winkle W, Mangum C (1975) Oxyconformers and oxyrequlators: a quantitative index. J Exp Mar Biol Ecol 17 . $103-110$

Weber JC, Epifanio CE (1996) Response of mud crab megalopae to cues from adult habitat. Mar Biol 126:655-661

Welch JM, Riltschof D, Bullock TM, Forward RB Ji (1997) 
Effects of chemical cues on settlement behavior of blue crab Callinectes sapidus postlarvae. Mar Ecol Prog Ser 154:143-153

Widdows J, Newell RIE, Mann R (1989) Effects of hypoxia and anoxia on survival, energy metabolism, and feeding of oyster larvae (Crassostrea virginica, Gmelin). Biol Bull $177: 154-166$

Williams AB (1984) Shrimps, lobsters and crabs of the Atlantic coast. Smithsonian Institution Press, Washington, DC

Wilson. KA, Heck KL Jr, Able KW (1987) Juvenile blue crab, Callinectes sapidus, survival: an evaluation of eelgrass,

Editorial responsibility: Otto Kinne (Editor), Oldendorf/Luhe, Germany
Zostera marina, as refuge. Fish Bull (Wash DC) 85:53-58 Wilson KA, A.ble KW, Heck KL Jr (1990) Predation rates on juvenile blue crabs in estuarine nursery habitats: evidence for the importance of macroalgae (Ulva lactuca). Mar Ecol Prog Ser 58:243-251

Wolcott DL, DeVries MD (1994) Offshore megalopae of Callinectes sapidus; depth of collection, molt stage and response to estuarine cues. Mar Ecol Prog Ser 109:157-163

Wolvekamp HP, Waterman TH (1960) Respiration. In: Waterman TH (ed) Physiology of the Crustacea. Academic Press, New York, p 35-91

Submitted: January 11, 1999; Accepted: August 9, 1999 Proofs received from author(s): March 2, 2000 